\title{
Possible Preventative/Rehabilitative Role of Gliflozins in OSA and T2DM. A Systematic Literature Review- Based Hypothesis
}

\author{
Vincenzo Maria Monda · Francesca Porcellati · Felice Strollo • \\ Alessandro Fucili · Marcello Monesi · Ersilia Satta · Sandro Gentile
}

Received: April 14, 2021 / Accepted: May 13, 2021 / Published online: July 17, 2021

(C) The Author(s) 2021

\section{ABSTRACT}

Obstructive sleep apnoea (OSA) is characterized by frequent apnoea episodes during sleep due to upper airway obstruction. The present review summarizes current knowledge on inter-relationships between OSA and type 2 diabetes mellitus (T2DM) and suggests the former as a possible target for sodium-glucose co-transporter-2 inhibitors (SGLT-2i). Based on pathophysiological mechanisms underlying OSA

V. M. Monda

Diabetes Unit "Santissima Annunziata" Hospital

Cento, Ferrara, Italy

e-mail: v.monda@ausl.fe.it

F. Porcellati

Section of Internal Medicine, Endocrinology and

Metabolism, Department of Medicine, Perugia

University School of Medicine, Perugia, Italy

e-mail: f.porcellati.fp@gmail.com

F. Strollo

Endocrinology and Diabetes, IRCCS San Raffaele Pisana, Rome, Italy

e-mail: felix.strollo@gmail.com

A. Fucili

Cardiovascular Research Center, Ferrara University, Ferrara, Italy

e-mail: fucilialessandro@gmail.com onset and renal SGLT-2 effects, we suggest that SGLT-2i indications might expand beyond current ones, including glucose, lipids, uric acid, blood pressure, and body weight control as well as chronic heart failure and kidney disease prevention.

Keywords: Obstructive sleep apnoea; SGLT-2i; Diabetes mellitus; Renal function; Vascular disease; Rehabilitation 


\section{Key Summary Points}

Obstructive sleep apnoea (OSA) is a syndrome often accompanying type 2 diabetes mellitus (T2DM) and precipitating severe cardiovascular events

The authors conducted a thorough, systematic literature search to analyze all interrelations known to date

This review summarizes current knowledge on inter-relationships between OSA and T2DM and on gliflozins (SGLT2is), i.e., innovative glucose-lowering drugs increasingly extensively utilized in T2DM because of their inherent null hypoglycaemic risk

Gliflozins also prove effective against impaired cardiovascular and renal function, and one of them, at least, does so even in the absence of T2DM

Based on the underlying pharmacological mechanisms, gliflozins might also be promising as preventative, rehabilitative, and therapeutic tools against OSA

\section{DIGITAL FEATURES}

This article is published with digital features, including a summary slide to facilitate understanding of the article. To view digital features for this article go to https://doi.org/10.6084/ m9.figshare. 14547447.

\section{INTRODUCTION}

Frequent episodes of apnoea characterize obstructive sleep apnoea (OSA) during sleep due to upper airways obstruction [1-2]. Its diagnosis relies on an altered oxygen desaturation index (ODI) [3], apnoea/hypopnoea index (AHI), respiratory disturbance index (RDI) and respiratory effort-related arousals (RERAs) [4-6], polysomnography (PSG) [7], and especially the association of typical symptoms (e.g., unrefreshing sleep, daytime sleepiness, fatigue or insomnia, awakening with a gasping or choking sensation, loud snoring, or witnessed apnoeas) with an RDI $\geq 5$ events per hour of sleep.

Despite being known for decades, OSA still has controversial clinical features, including unrefreshing sleep, daytime fatigue, and impaired concentration, requiring further investigation [8-10].

According to the so-called Chicago criteria [11], OSA's severity is given by the AHI value as follows: absent $(<5)$, mild $(5-14)$, moderate (15-29), and severe ( $\geq 30)$ [2].

\section{Aim}

The present review aims to summarize current knowledge on inter-relationships between OSA and type 2 diabetes mellitus (T2DM) and suggests the former as a possible target for sodiumglucose co-transporter-2 inhibitors (SGLT-2i). This way, SGLT-2i indications might expand further beyond current ones, including glucose, lipids, uric acid, blood pressure, and body weight control as well as chronic heart failure and kidney disease prevention.

\section{METHODS}

The information contained in the present review comes from a thorough analysis of the literature concerning T2DM, OSA, and SGLT2.is. Online databases (PubMed, Embase, Scopus, and Web of Science) were systematically searched for English-language publications dealing with any relationship between T2DM, related complications, or frequently associated diseases and OSA up to October 2020. The reference list of included papers also served as an additional source of information on the topic. A group of keywords was used in the systematic search, including: "OSA" or "T2DM" or "T2DM complication") AND ("T2DM comorbidities" OR "cardiometabolic" OR glycaemia OR "insulin resistance" OR "inflammatory Cytokines" OR "obesity" OR "leptin" OR "SGLT2-1) AND ("trial" OR "randomization*" OR "control" OR 
"clinical" OR "meta-analysis"). Studies meeting the following criteria were excluded: $<2$-week duration, non-randomized clinical trials, and cross-sectional studies.

Two independent reviewers (MM and SG) completed the data extraction process according to eligibility criteria. First, they evaluated paper quality by the bias assessment tool, according to the following domains: random sequence generation (selection bias), allocation concealment (selection bias), blinding of participants and personnel (performance bias), blinding of outcome assessment (detection bias), incomplete outcome data (attrition bias), and selective reporting (reporting bias). Then, they classified each domain as: "low risk of bias", "high risk of bias", or "unclear risk of bias". Finally, based on the results obtained from the domains, they defined the overall quality of such studies as good (low risk for more than three domains), acceptable (low risk for three domains), and poor (low risk for less than three domains). This method allowed selecting 66 highly specific papers and 138 related publications.

No statistical analysis was possible or required as our paper is a review.

\section{RESULTS}

We systematized all the information collected from the literature under separate sections devoted to individual conditions and organspecific pathologies.

\section{Epidemiology}

OSA has an estimated 3:1 to 5:1 male-to-female ratio [12] and is 2-3-fold more prevalent in older adults ( $>65$ years) [13-14]. Among middle-aged people, estimated symptomatic OSA's prevalence is about $4 \%$ in men and $2 \%$ in women [15], and asymptomatic OSA's prevalence is $20-30 \%$, with a failed detection risk as high as $93 \%$ in women and $82 \%$ in men [16]. However, in the overall male adult population, it is even as high as $50 \%$ [17-18], with a continuously increasing trend within the developed countries, partly due to the parallel increase of the obesity rate [19].

Indeed, a major risk factor for OSA is visceral obesity [12, 20-22]. The higher the obesity degree, the more severe OSA is, with a close association with hypertension, coronary and cerebral vascular disease, and significantly increased all-cause mortality among people with untreated sleep disorders regardless of age, sex, and body mass index (BMI) [23]. In aged subjects, the ODI proved to be significantly associated with T2DM and three components of the metabolic syndrome, including hyperglycemia, hypertriglyceridemia, and essential arterial hypertension (EAH) [24].

\section{OSA and T2DM}

An extremely variable prevalence of OSA in T2DM has been reported [25-30], mostly ranging from $24 \%$ to $36 \%$ [31-32], and sometimes even $70 \%$ [12]. The risk for T2DM in patients with OSA, in turn, has been well known for decades. It ranges $30-71 \%$ and is higher for an AHI > 30 [31-34]. In addition, diabetes-related foot disease, insulin treatment, obesity, coronary heart disease (CHD), and depression are the most relevant risk factors for OSA in T2DM patients [35].

\section{OSA and Autonomic Nervous System Dysfunction}

The pathophysiological link between T2DM and OSA might be, at least in part, the activation of the sympathetic branch of the autonomic nervous system (ANS) by acute hypoxia occurring during sleep apnoea/hypopnoea episodes and consequent night respiratory effortrelated arousals (RERAs) [36], eventually exacerbated by hypercapnia [37]. Consequential massive catecholamine release results in insulin resistance both directly and through increased cortisol output [38], contributing to a feed-forward cascade of adverse events generated by sleep loss, sleep fragmentation, hypoxia, and leading to weight gain, insulin resistance, and T2DM [39]. 
Moreover, aortic and carotid chemoreceptors, which regulate the SNS activity in response to changes in $\mathrm{pH}$ values, hypoxia, and hypercapnia, are activated, especially in patients with OSA and metabolic syndrome [40-41]. In normal sleep, despite eliciting increased central SNS outflow, hypoxic or hypercapnic chemoreflex activation triggers hyperventilation as well, which, in turn, inhibits SNS activity [40, 42-43]. Moreover, chemoreceptor-related SNS activation increases blood pressure (BP), which attenuates chemoreflex outputs through carotid arterial baroreceptors 43 , i.e., the mechanism underlying the $10-20 \%$ nighttime, sleep stagerelated BP lowering compared to waking hours observed in healthy subjects, known as "nocturnal BP dipping" [44-45].

Conversely, the peripheral chemoreflex triggered by apnoea-dependent hypoxia and hypercapnia without hyperventilation results in SNS-dependent vasoconstriction [40] and, when repeating over time, impairs carotid sinus and aortic baroreceptor sensitivity [46]. Consequently, any longstanding apnoea/hypopnoea syndrome may cause baroreceptors to "reset" at higher baseline BP levels throughout the day [40], thus precipitating chronic SNS activation [47-48] with increased BP and heart rate (HR). EAH and other adverse cardiovascular outcomes [40] will follow soon, thus suggesting to take the "non-dipping" phenomenon as a clinical marker of increased risk for OSA in hypertensive patients [40]. However, nighttime continuous positive airway pressure (CPAP) can counteract both chemoreceptor over-activation and baroreceptor hyporesponsiveness [49-52].

Therefore, OSA can exacerbate preexisting autonomic nervous system (ANS) dysfunction in T2DM patients. Indeed, patients with $\mathrm{EAH}+\mathrm{T} 2 \mathrm{DM}$ undergo more prominent peripheral SNS activation signs and insulin levels than those with either disease [53], which suggests that ANS dysfunction may be related to increased plasma insulin levels in those patients [53].

Moreover, in people with T2DM and cardiovascular autonomic neuropathy (CAN) an imbalance between SNS and parasympathetic vagus nerve (VN) activity was described due to either an absolute or a relative decrease in $\mathrm{VN}$ firing rate [54]. This may represent another selfsustained pathophysiological mechanism underlying SNS hyperactivity in the presence of OSA [12].

As opposed to what was observed in type 1 diabetes mellitus (T1DM), in patients with recent-onset T2DM, the decrease in cardiac VN activity and baroreflex sensitivity is strongly associated with hepatic steatosis, thus suggesting the latter to have a role in early hypoparasympathetic-type CAN in T2DM [55]. However, to describe this mechanism in greater detail, we have to outline that, despite insulin resistance contributing to early cardiovagal suppression in both DM types, the lower glucagon-stimulated insulin levels compensatorily increase parasympathetic tone in T1DM [56]. CAN has been reported to occur early in T2DM with a prevalence of $1.8 \%$ - or up to $15.3 \%$ when defined by the presence of at least two borderline and one pathological test, suggesting the need for ruling out CAN as early as possible in patients with T2DM [57].

According to some authors, OSA may induce resistance to body weight (BW)-lowering effects exerted by leptin [58] through $\beta$-3 lipolytic adipose tissue receptors [59]. The underlying mechanism seems to be SNS hyperactivity-related receptor downregulation with compensatory increased leptin concentrations [60] and consequent increased pro-inflammatory cytokine secretion [61-62]. Also, due to the selective nature of leptin-resistance, i.e., preserving cardiovascular effects [63], leptin-associated enhanced sympathetic nerve outflow [60] increases BP [64] and HR, thus paving the way to cardiovascular complications [65-66].

\section{OSA and Diabetic Peripheral Neuropathy}

A strong association also exists between OSA and diabetic peripheral neuropathy (DPN), being the rate of distal electroneurographically detected polyneuropathy twice as high in patients with newly diagnosed OSA as in controls $(71 \%$ vs. $33 \%$, respectively, $p<0.01)$ and improving significantly after nasal continuous positive airway pressure treatment (CPAP) [67-68]. 
DPN seems to have a $35.2 \%$ rate in mixed T1DM and T2DM [69] and to be significantly associated with OSA in T2DM patients [70]. Indeed, OSA occurs more frequently in T2DM patients with DPN [71], where it comes preferentially with lower intra-epidermal nerve fiber density, poly-adenosine-diphosphoribose polymerase (PARP) activation, and diabetic foot ulceration [72], most likely due to increased nitrosative/oxidative stress, and impaired microvascular regulation [70].

\section{OSA and Diabetic Kidney Disease}

OSA is also significantly associated with diabetic kidney disease (DKD) - even at its early stagesand any other diabetes-related complications in T2DM [73], probably as a result of AH [74].

Baseline OSA parameters, especially AHI, are independent predictors of future estimated glomerular filtration rate (eGFR) absolute value and change over time (i.e., 2.5 years on average). After controlling for multiple confounders, including OSA, the serum nitrotyrosine concentration emerges as an independent predictor of final eGFR and of eGFR change over time [75].

Also, CAN is an independent predictor of 9.6-year eGFR decline [76], with a significant association with CKD onset [77], thus suggesting that CAN can further exacerbate OSA-related damage to the kidney in patients with T2DM and OSA [75].

OSA was also associated with CKD in patients without diabetes in several cross-sectional and longitudinal observational studies, mainly depending on disease severity [78-82]. Moreover, patients with end-stage renal disease (ESRD) have a $50 \%$ to $60 \%$ prevalence of OSA [83-85] in favour of a two-way and mutual association between CKD and OSA [86].

\section{OSA and Diabetic Retinopathy}

Although the association between OSA and diabetic retinopathy (DR) has been a controversial issue in the past [87], a recent, large meta-analysis suggests OSA is significantly associated with increased DR risk in both DM types [88]. The association between DR (29\% non-proliferative [NPDR] and $48 \%$ proliferative [PDR]) and sleep-disordered breathing (SDB) is robust [88-90]. Also, intermittent nocturnal hypoxia and related desaturation/reoxygenation phenomena are supposed to be the main underlying mechanisms [88-90], with intermittent nocturnal hypoxia and related desaturation/reoxygenation phenomena supposed to be the main underlying mechanisms [89-90] together with the nocturnal "non-dipping" phenomenon and daytime BP variability independently increasing the risk for cardiovascular diseases [91] and retinopathy in patients with T2DM [92]. Also, OSA is known to be an independent factor predicting progression to preproliferative/proliferative DR (OR, 5.2,95\% CI 1.2-23.0, $p=0.03$ ) [91], thus likely having a prominent role in the pathogenesis of severe sight-threatening clinical pictures [93].

\section{Macrovascular Complications}

OSA is associated with diabetic macrovascular complications, most often coronary heart disease (CHD) and stroke, atrial fibrillation (AF), and heart failure (HF) [94], and SDB acts as a predictor of incident $\mathrm{CHD}, \mathrm{AF}$, and $\mathrm{HF}$ [95].

Several data collected in obese patients with T2DM show the most severe AHI scores associated with an increased risk of major CV events [96-98]. For example, the cross-sectional, longitudinal adult-population-based Wisconsin Sleep Cohort Study showed that moderate to severe SDB (AHI > 20) was significantly associated with the prevalence of stroke over the next 4 years and might even contribute to the occurrence of such an event [99].

In the Sleep Heart Health Study (SHHS)-a multi-centre, prospective cohort study on cardiovascular consequences of OSA initiated in 1994-the association between OSA and stroke proved significant only in men after controlling for all possible covariates (OR 2.86, CI 1.10, 7.39) [100]. Also, after adjusting for multiple risk factors, OSA proved to be a significant predictor of incident CHD (myocardial infarction, revascularization procedure, or CHD death) only in men $\leq 70$ years of age [101]. 
In conclusion, OSA seems to be associated with an increased risk for stroke rather than CHD.

\section{Pathophysiology of T2DM Micro- macrovascular Complications in Patients with OSA}

The bidirectional association between OSA and T2DM also involves microvascular and macrovascular complications [102-103]. Advanced glycation end product (AGE) accumulation along with increased protein kinase $\mathrm{C}$, polyol, and hexosamine pathway activity could lead to the overexpression of reactive oxygen species (ROS) and pro-inflammatory cytokines, all of which have a role in diabetic complications [70, 104-108]. Indeed, some papers suggest an association between OSA and markedly increased intracellular ROS concentrations [including mainly superoxide ion $\left(\mathrm{O}^{-}\right)$, nitric oxide (NO), and hydrogen peroxide $\left.\left(\mathrm{H}_{2} \mathrm{O}_{2}\right)\right]$, which, by overwhelming antioxidant capacity, chemically modify lipidic, protidic, and DNA macromolecules [109-114].

Based on such mechanisms, chronic intermittent hypoxia $(\mathrm{CIH})$ proves to induce overall pancreatic beta-cell dysfunction in mice through increased mitochondrial ROS concentrations, resulting in insulin resistance, defective proinsulin processing, and impaired glucose-stimulated insulin secretion. A mitochondrial ROS-scavenger treatment, in turn, can restore such changes [111].

Thus, referring to OSA-diabetes interactions, repeated nocturnal hypoxia/re-oxygenation episodes contribute to common pathogenic mechanisms of micro- and macro-vascular diabetic complications. This occurs essentially through apnoeic-dependent lower oxygen availability and subsequent reoxygenation-related ROS formation at breath resumption [102], further increasing oxidative stress-related systemic inflammation, endothelial cell dysfunction, SNS, and renin-angiotensin system activation in a self-sustained vicious cycle [102].

Indeed, exceptionally high levels of pro-inflammatory cytokines including tumor necrosis factor (TNF)- $\alpha$, interleukin-6 (IL-6) and IL-8, and
C-reactive protein-also widely recognized as significant cardiovascular risk markers-are in common in both OSA [115-118] and T2DM patients [119-121] and decrease after continuous positive airway pressure (C-PAP) treatment [122].

Also, AGE generation and tissue accrual resulting from covalent, non-enzymatic binding between glucides (endowed with reducing properties) and lipid, protein, or nucleic acid amine residues cause cell damage, eventually contributing to diabetic microvascular complications in people with T2DM and OSA [102]. However, CIH is known to induce elevated circulating AGE levels as a function of OSA severity in nondiabetic patients too [123-124] and, in that case, may play a crucial role in insulin resistance, thus entailing a high risk for T2DM onset [125].

Another pathophysiological link between OSA and diabetic micro-/macrovascular complications is the upregulation of RAS, which can be detrimental to renal function [86]. Indeed, several cross-sectional [126-127] and longitudinal studies [128-130] showed a CKD-to-OSA association even in patients without T2DM. For example, in a study carried out in China on 1259 critically ill patients (183 with a history of OSA), the incidence of acute kidney injury (AKI) in patients with OSA was higher compared with those without OSA (41 vs. $57 \%, p<0.001$ ) and, at multivariate analysis controlling for age, gender, race, and chronic and acute risk factors, an independent association was apparent between OSA and AKI (OR 1.53, 95\% CI 1.04-2.24, $p=0.031$ ) [131-132]. Such a detrimental effect of OSA on renal function may be attenuated by long-term C-PAP therapy [132] through improved insulin resistance, especially in the case of associated obesity [133].

In conclusion, C-PAP treatment of OSA may improve T2DM-related insulin resistance and inflammatory status, thus reducing the progression of micro-/macrovascular T2DM complications. However, the effects of other therapeutic interventions on patients with T2DM and OSA still await clarification. 


\section{Can Innovative Antihyperglycaemic Drugs Improve Both OSA and Its Clinical Consequences?}

Besides exerting impressive antihyperglycaemic effects, SGLT-2is prove favourable at both the cardiovascular and renal levels [134-142]. The four currently available drugs from this class (canagliflozin, dapagliflozin, empagliflozin, and ertugliflozin) ensure $90 \%$ active tubular resorption inhibition of glucose from glomerular filtrate [143-146], despite the remaining 10\% being still reabsorbed through SGLT-1 receptors [147].

The already mentioned T2DM-related overactive SNS causes widespread kidney chemoreceptors and baroreceptors to send activating signals back to the brain, thus triggering a selfsustained mechanism involving RAS stimulation, increased systemic BP, and CKD progression [148]. Contrarily, SGLT-2is seem to reduce SNS overactivity at least partially through increased renal tubular glucose resorption [149], thus strongly contributing to observed lower cardiovascular risk and hospitalization rates [150-151].

Based on animal models of DKD [152-154], the mechanism behind favourable SGLT-2i renal effects seems to be the activation of the socalled tubule-glomerular feedback (TGF) as described below. TGF consists of the A1-adenosine receptor-mediated afferent glomerular arteriole vasoconstriction [155] in response to increased $\mathrm{NaCl}$ load to distal tubule [156-157]. Briefly, adenosine is known to act as a paracrine signal through three receptor types, i.e., A1, A2 (further classified into high-affinity A2a and low-affinity A2b subtypes), and A3 [157]. A2a and $\mathrm{A} 2 \mathrm{~b}$ receptor activation attenuates TGF response by inhibiting afferent glomerular arteriole vasoconstriction through adenylate cyclase-dependent cyclic adenose monophosphate (c-AMP) generation [158-159]. Contrarily, c-AMP production is inhibited by A1 receptor activation, while $\mathrm{A} 3$ receptor function is still unclear [158]. Such physiological mechanisms allow the kidney to contribute to BP regulation through renin release by the cells from the juxtaglomerular apparatus (JGA). These cells "interpret" increased $\mathrm{NaCl}$ load to the distal tubular region as a sign of extracellular fluid expansion, thus activating TGF and causing afferent glomerular arteriole vasoconstriction [160]. Therefore, it is conceivable that TGF activation is the physiological mechanism responsible for reduced SNS overactivation contributing to cardiovascular and renal SGLT$2 \mathrm{i}$ benefits as referred to OSA [150].

An additional favourable SGLT-2i effect on OSA, also resulting from the TGF activation mentioned above, may come from the recently identified evidence that, as opposed to T1DM patients [161], the glucose-dependent osmotic diuretic effect of SGLT-2i is not associated with increased RAS activity in T2DM patients [162]. Also, an experimental study performed in the T2DM animal model showed that the plasma renin activity or serum aldosterone level did not increase after dapagliflozin treatment [163].

Another possible favourable effect of SGLT2is on clinical signs of OSA might come from increased hematocrit $(\mathrm{Ht})$, which might further contribute to a reduced cardiovascular death (CD) rate [164]. Indeed, SGLT-i stimulation activates the adenosine-triphosphate (ATP)-dependent $\mathrm{Na}+-\mathrm{K}+$ pump to actively export intracellular $\mathrm{Na}+$ into the blood vessels against a concentration gradient, thus depleting ATP and $\mathrm{O}_{2}$ reserve [165]. The consequent $\mathrm{pO}_{2}$ decrease determines functional exhaustion of renal tubular cells, thus inducing pro-inflammatory cytokine release, progressive interstitial injury, and subsequent fibrosis [166] through the transformation of fibroblasts into myofibroblasts [167], which, due to their lower erythropoietin secretory capacity, contribute to typical DKD-related anaemia [168]. Ht slowly increases within the first 2 months into SGLT-2i treatment independently of haemoconcentration and settles down after that [169]. Indeed, opposite to what was observed for the diuretic agent hydrochlorothiazide, erythropietin levels and reticulocyte count seem to increase in T2DM following dapagliflozin administration [170]. Indeed, opposite to what is observed for the diuretic agent hydrochlorothiazide, erythropietin levels and reticolocyte count seem to increase in T2DM following dapagliflozin administration [170]. Furthermore, increased erythropoietin levels $(63 \%, p=0.0078)$ were 
found following empagliflozin treatment in patients with T2DM with preserved renal function (eGFR $\geq 60 \mathrm{ml} \cdot \mathrm{min}^{-1} \cdot 1.73 \mathrm{~m}^{-2}$ ) compared to control subjects [171].

Finally, SGLT-2i-related weight loss, due to visceral and subcutaneous adipose tissue reduction [172-174], may have a favourable effect on OSA. As shown in animal models of T2DM and metabolic syndrome, it depends on a sustained shift in energy substrates from carbohydrates to lipids with enhanced fatty-acid betaoxidation-related lipolysis [175-179], which proved to improve liver steatosis in T2DM patients and in T2DM animal models [180-184] and, as observed with canagliflozin, CHD-associated epicardial fat accumulation [185-187].

\section{CONCLUSIONS AND FUTURE PERSPECTIVES}

As already shown for HF and CKD, the pharmacological properties of SGLT-2is are suggestive of a potential role in the treatment of OSA independently of T2DM $[136,139,141]$. The most likely mechanisms involved in such beneficial effects of SGLT-2is on OSA are reported in Fig. 1 and can be summarized as follows: (1) sympathetic activity inhibiting effects [150, 188], expected to improve both associated CAN and cardiovascular and renal outcomes significantly [54]; (2) direct benefits on renal function [140-141], preventing associated CAN from further self-sustaining kidney function impairment [76-77, 86]; (3) Ht increasing effects, expected to reduce nighttime hypoxia [189-191].

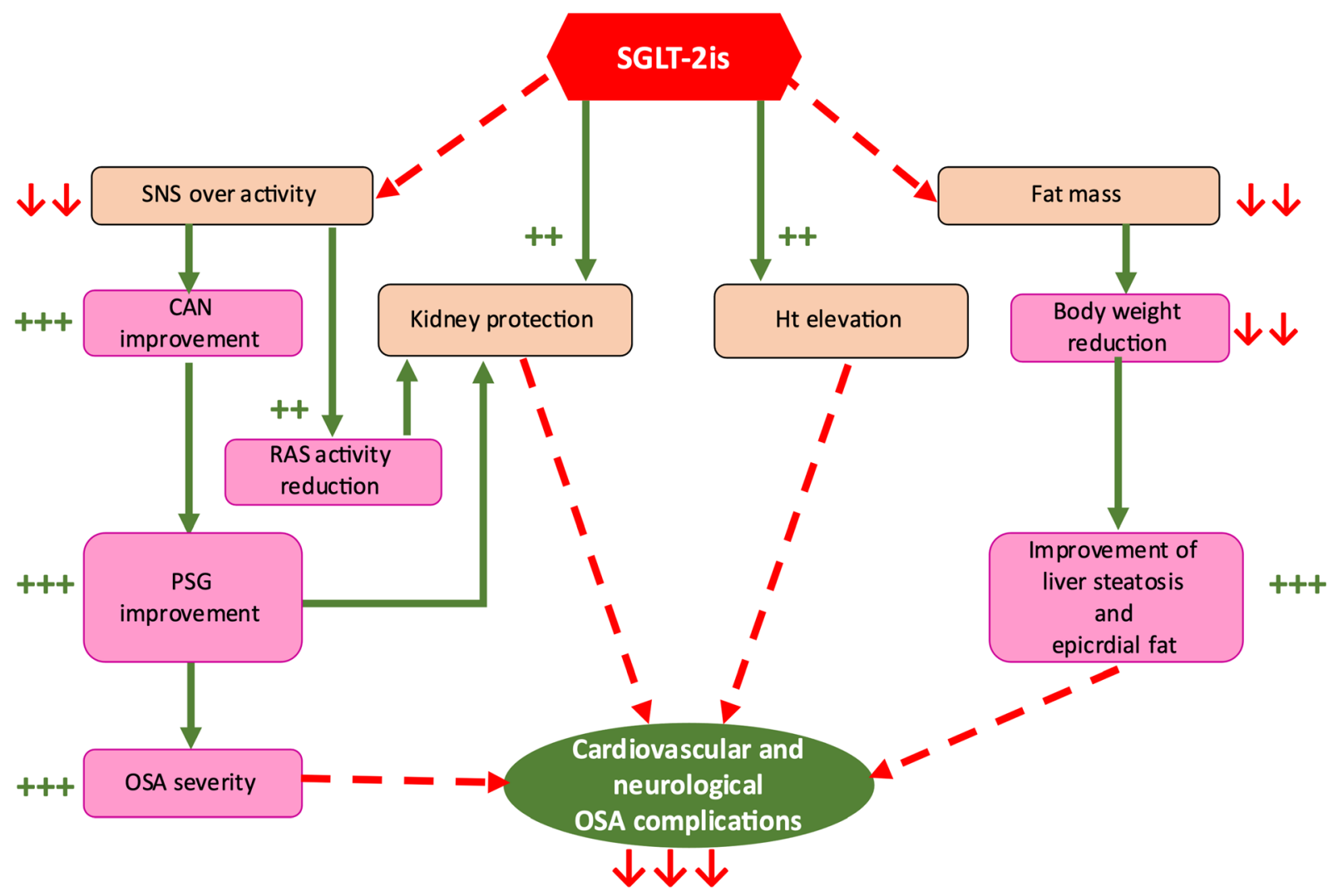

Fig. 1 The putative favourable effects of SGLT-2is on OSA. CAN cardiovascular autonomic neuropathy, $H T$ haematocrit, $O S A$ obstructive sleep apnoea, $P S G$ polysomnography, $R A S$ renin angiotensin system, $S G L T$ 2 is sodium/glucose co-transporter-2 inhibitors, $S N S$ sympathetic nervous system. See text for details 
Currently, only a few, yet promising, data are available on the effects of SGLT2-i in T2DM patients with OSAS, showing a marked decrease of AHI $(31.9 \pm 18.0$ to $18.8 \pm 11.5$ events $/ \mathrm{h}$; $p=0.003)$, HbA1c, body weight, and BMI in the absence of any BP changes [192-193]. Also, in a metformin add-on study, differently from glimepiride, dapagliflozin significantly decreased the AHI and Epworth Somnolence Scale, triglycerides, and systolic and diastolic BP and increased oxygen saturation and high-density lipoprotein cholesterol (HDL-C) [161, 193-195].

Moreover, empagliflozin proved beneficial for cardiovascular and renal outcomes regardless of OSA but could also reduce the risk for OSA [196] by counteracting the hyperproduction and the hyperactivity of leptin [197], whose levels are elevated in OSA patients [65]. The latter hypothesis is still controversial [198]. However, based on a recent meta-analysis of ten randomized controlled trials, SGLT2i treatment is associated with decreased leptin and increased adiponectin levels in T2DM patients, eventually contributing to metabolic SGLT-2i benefits [199].

In conclusion, it is conceivable that the use of SGLT-2is will represent a promising preventative, rehabilitative, and therapeutic approach for OSA patients regardless of coexisting diabetes by also slowing CKD progression and managing CAN, both known to be closely associated with OSA and T2DM. Thus, these drugs might exert beneficial effects on CAN, and, as CAN is a very early diabetes and OSA complication [57], might be particularly indicated in the early stages of both diseases to reduce associated mortality risk [54, 188].

Indeed, expected OSA benefits might add to the already established cardiovascular and renal preventative effect of dapagliflozin in animal T2DM models [163], and in humans, even in the absence of T2DM as well [200].

Further clinical studies involving patients with and without diabetes are needed to confirm our hypothesis on SGLT-2is benefits in OSA rehabilitation and management and assess whether such benefits reflect a single drug or a whole class effect.

\section{ACKNOWLEDGEMENTS}

This article is based on previously conducted studies and does not contain any new studies with human participants or animals performed by any of the authors. We acknowledge the logistic complimentary support of Nefrocenter Research Network and Nyx, research startup, Naples, Italy.

Funding. No funding or sponsorship was received for this study or publication of this article.

Authorship. All authors meet the International Committee of Medical Journal Editors (ICMJE) criteria for authorship for this article, take responsibility for the integrity of the work as a whole, have given their approval for this version to be published and assure it will not be published elsewhere in the same form, in English or in any other language, including electronically.

Authorship Contributions. Vincenzo Maria Monda, Sandro Gentile, and Felice Strollo created the paper and wrote it, Vincenzo Maria Monda, Sandro Gentile, and Francesca Porcellati extensively reviewed the literature, and all approved the final manuscript.

Compliance with Ethical Guidelines. This study has been conducted in conformance with good clinical practice standards, is based on previously published studies and does not contain any studies with human participants or animals performed by any of the authors.

Disclosures. Vincenzo Maria Monda, Alessandro Fucili, Sandro Gentile, Marcello Monesi Francesca Porcellati, Ersilia Satta, and Felice Strollo have nothing to disclose in relation to this article.

Data Availability. Data sharing is not applicable to this article as no datasets were generated or analyzed during the current study.

Open Access. This article is licensed under a Creative Commons Attribution- 
NonCommercial 4.0 International License, which permits any non-commercial use, sharing, adaptation, distribution and reproduction in any medium or format, as long as you give appropriate credit to the original author(s) and the source, provide a link to the Creative Commons licence, and indicate if changes were made. The images or other third party material in this article are included in the article's Creative Commons licence, unless indicated otherwise in a credit line to the material. If material is not included in the article's Creative Commons licence and your intended use is not permitted by statutory regulation or exceeds the permitted use, you will need to obtain permission directly from the copyright holder. To view a copy of this licence, visit http:// creativecommons.org/licenses/by-nc/4.0/.

\section{REFERENCES}

1. Somers VK, White DP, Amin R, American Heart Association Council for High Blood Pressure Research Professional Education Committee, Council on Clinical Cardiology, American Heart Association Stroke Council; American Heart Association Council on Cardiovascular Nursing, American College of Cardiology Foundation, et al. Sleep apnea and cardiovascular disease: an American Heart Association/American College Of Cardiology Foundation Scientific Statement from the American Heart Association Council for High Blood Pressure Research Professional Education Committee, Council on Clinical Cardiology, Stroke Council, and Council On Cardiovascular Nursing. In collaboration with the National Heart, Lung, and Blood Institute National Center on Sleep Disorders Research (National Institutes of Health). Circulation. 2008;118(10):1080-111. https://doi.org/10. 1161/CIRCULATIONAHA.107.189375.

2. Epstein LJ, Kristo D, Strollo PJ Jr, et al. Adult Obstructive Sleep Apnea Task Force of the American Academy of Sleep Medicine. Clinical guideline for the evaluation, management and long-term care of obstructive sleep apnea in adults. J Clin Sleep Med. 2009;5(3):263-76.

3. Sateia MJ. International classification of sleep disorders-third edition: highlights and modifications. Chest. 2014;146(5):1387-94. https://doi.org/10. 1378/chest.14-0970.
4. Shaw JE, Punjabi NM, Wilding JP, Alberti KG, Zimmet PZ, International Diabetes Federation Taskforce on Epidemiology and Prevention. Sleep-disordered breathing and type 2 diabetes: a report from the International Diabetes Federation Taskforce on Epidemiology and Prevention. Diabetes Res Clin Pract. 2008;81(1):2-12. https://doi.org/10.1016/j. diabres.2008.04.025.

5. American Academy of Sleep Medicine. International classification of sleep disorders. 3rd ed. Darien: American Academy of Sleep Medicine; 2014.

6. Kapur VK, Auckley DH, Chowdhuri S, et al. Clinical practice guideline for diagnostic testing for adult obstructive sleep apnea: an American Academy of sleep medicine clinical practice guideline. J Clin Sleep Med. 2017;13(3):479-504. https://doi.org/10. 5664/jcsm. 6506 .

7. Malhotra RK, Kirsch DB, Kristo DA, American Academy of Sleep Medicine Board of Directors, et al. Polysomnography for obstructive sleep apnea should include arousal-based scoring: an American Academy of sleep medicine position statement. J Clin Sleep Med. 2018;14(7):1245-7. https://doi. org/10.5664/jcsm.723.

8. Mannarino MR, Di Filippo F, Pirro M. Obstructive sleep apnea syndrome. Eur J Intern Med. 2012;23(7):586-93. https://doi.org/10.1016/j.ejim. 2012.05.013.

9. De Backer W. Obstructive sleep apnea/hypopnea syndrome. Panminerva Med. 2013;55(2):191-5.

10. Lee W, Nagubadi S, Kryger MH, Mokhlesi B. Epidemiology of obstructive sleep apnea: a populationbased perspective. Expert Rev Respir Med. 2008;2(3):349-64. https://doi.org/10.1586/ 17476348.2.3.349.

11. Sleep-related breathing disorders in adults: recommendations for syndrome definition and measurement techniques in clinical research. The report of an American Academy of sleep medicine task force. Sleep. 1999;22(5):667-89.

12. Greco C, Spallone V. Obstructive sleep apnoea syndrome and diabetes. Fortuitous association or interaction? Curr Diabetes Rev. 2015;12(2):129-55. https://doi.org/10.2174/ 1573399811666150319112611.

13. Ancoli-Israel S, Gehrman P, Kripke DF, et al. Longterm follow-up of sleep disordered breathing in older adults. Sleep Med. 2001;2(6):511-6. https:// doi.org/10.1016/s1389-9457(00)00096-4.

14. Durán J, Esnaola S, Rubio R, Iztueta A. Obstructive sleep apnea-hypopnea and related clinical features in a population-based sample of subjects aged 30 to 
70 yr. Am J Respir Crit Care Med. 2001;163(3 Pt 1): 685-9. https://doi.org/10.1164/ajrccm.163.3. 2005065.

15. Young T, Palta M, Dempsey J, Skatrud J, Weber S, Badr S. The occurrence of sleep-disordered breathing among middle-aged adults. $\mathrm{N}$ Engl J Med. 1993;328(17):1230-5. https://doi.org/10.1056/ NEJM199304293281704.

16. Young T, Evans L, Finn L, Palta M. Estimation of the clinically diagnosed proportion of sleep apnea syndrome in middle-aged men and women. Sleep. 1997;20:705-6.

17. Heinzer R, Vat S, Marques-Vidal P, et al. Prevalence of sleep-disordered breathing in the general population: the HypnoLaus study. Lancet Respir Med. 2015;3(4):310-8. https://doi.org/10.1016/S22132600(15)00043-0.

18. Arnardottir ES, Bjornsdottir E, Olafsdottir KA, Benediktsdottir B, Gislason T. Obstructive sleep apnoea in the general population: highly prevalent but minimal symptoms. Eur Respir J. 2016;47(1): 194-202. https://doi.org/10.1183/13993003.011482015.

19. Peppard PE, Young T, Barnet JH, Palta M, Hagen EW, Hla KM. Increased prevalence of sleep-disordered breathing in adults. Am J Epidemiol. 2013;177(9):1006-14. https://doi.org/10.1093/aje/ kws342.

20. Young T, Skatrud J, Peppard PE. Risk factors for obstructive sleep apnea in adults. JAMA. 2004;291(16):2013-6. https://doi.org/10.1001/ jama.291.16.2013.

21. Vijayan VK. Morbidities associated with obstructive sleep apnea. Expert Rev Respir Med. 2012;6(5): 557-66. https://doi.org/10.1586/ers.12.44.

22. Young T, Palta M, Dempsey J, Peppard PE, Nieto FJ, Hla KM. Burden of sleep apnea: rationale, design, and major findings of the Wisconsin sleep cohort study. WMJ. 2009;108:246-9.

23. Young T, Finn L, Peppard PE, et al. Sleep disordered breathing and mortality: eighteen-year follow-up of the Wisconsin sleep cohort. Sleep. 2008;31:1071-8.

24. Assoumou HG, Gaspoz JM, Sforza E, et al. Obstructive sleep apnea and the metabolic syndrome in an elderly healthy population: the SYNAPSE cohort. Sleep Breath. 2012;16:895-902. https://doi.org/10. 1007/s11325-011-0593-y.

25. Foster GD, Sanders MH, Millman R, Sleep AHEAD Research Group, et al. Obstructive sleep apnea among obese patients with type 2 diabetes. Diabetes
Care. 2009;32:1017-9. https://doi.org/10.2337/ dc08-1776.

26. Fredheim JM, Rollheim J, Omland T, et al. Type 2 diabetes and pre diabetes are associated with obstructive sleep apnea in extremely obese subjects: a cross-sectional study. Cardiovasc Diabetol. 2011;10:84. https://doi.org/10.1186/1475-2840-1084.

27. Resnick HE, Redline S, Shahar E, Sleep Heart Health Study, et al. Diabetes and sleep disturbances: findings from the Sleep Heart Health Study. Diabetes Care. 2003;26:702-9. https://doi.org/10.2337/ diacare.26.3.702.

28. Laaban JP, Daenen S, Léger D, et al. Prevalence and predictive factors of sleep apnoea syndrome in type 2 diabetic patients. Diabetes Metab. 2009;35:372-7. https://doi.org/10.1016/j.diabet.2009.03.007.

29. Lecube A, Sampol G, Lloberes P, et al. Diabetes is an independent risk factor for severe nocturnal hypoxemia in obese patients. A case-control study. PLoS ONE. 2009;4:e4692. https://doi.org/10.1371/ journal.pone.0004692.

30. Aronsohn RS, Whitmore H, Van Cauter E, Tasali E. Impact of untreated obstructive sleep apnea on glucose control in type 2 diabetes. Am J Respir Crit Care Med. 2010;181:507-13. https://doi.org/10. 1164/rccm.200909-1423OC.

31. Lam DC, Lui MM, Lam JC, Ong LH, Lam KS, Ip MS. Prevalence and recognition of obstructive sleep apnea in Chinese patients with type 2 diabetes mellitus. Chest. 2010;138:1101-7. https://doi.org/ 10.1378/chest.10-0596.

32. Einhorn D, Stewart DA, Erman MK, Gordon N, Philis-Tsimikas A, Casal E. Prevalence of sleep apnea in a population of adults with type 2 diabetes mellitus. Endocr Pract. 2007;13:355-62. https://doi.org/ 10.4158/EP.13.4.355.

33. Kendzerska T, Gershon AS, Hawker G, Tomlinson G, Leung RS. Obstructive sleep apnea and incident diabetes. A historical cohort study. Am J Respir Crit Care Med. 2014;190(2):218-25. https://doi.org/10. 1164/rccm.201312-2209OC.

34. Nagayoshi M, Punjabi NM, Selvin E, et al. Obstructive sleep apnea and incident type 2 diabetes. Sleep Med. 2016;25:156-61. https://doi.org/10.1016/j. sleep.2016.05.009.

35. Subramanian A, Adderley NJ, Tracy A, et al. Risk of incident obstructive sleep apnea among patients with type 2 diabetes. Diabetes Care. 2019;42(5): 954-63. https://doi.org/10.2337/dc18-2004. 
36. Arnardottir ES, Mackiewicz M, Gislason T, Teff KL, Pack AI. Molecular signatures of obstructive sleep apnea in adults: a review and perspective. Sleep. 2009;32(4):447-70. https://doi.org/10.1093/sleep/ 32.4.447.

37. Narkiewicz K, Somers VK. Sympathetic nerve activity in obstructive sleep apnoea. Acta Physiol Scand. 2003;177(3):385-90. https://doi.org/10.1046/j. 1365-201X.2003.01091.x.

38. Guyon A, Balbo M, Morselli LL, et al. Adverse effects of two nights of sleep restriction on the hypothalamic-pituitary-adrenal axis in healthy men. J Clin Endocrinol Metab. 2014;99(8):2861-8. https://doi. org/10.1210/jc.2013-4254.

39. Spiegel K, Knutson K, Leproult R, Tasali E, Van Cauter E. Sleep loss: a novel risk factor for insulin resistance and type 2 diabetes. J Appl Physiol (1985). 2005;99(5):2008-19. https://doi.org/10. 1152/japplphysiol.00660.2005.

40. Mansukhani MP, Kara T, Caples SM, Somers VK. Chemoreflexes, sleep apnea, and sympathetic dysregulation. Curr Hypertens Rep. 2014;16(9):476. https://doi.org/10.1007/s11906-014-0476-2.

41. Trombetta IC, Maki-Nunes C, Toschi-Dias E, et al. Obstructive sleep apnea is associated with increased chemoreflex sensitivity in patients with metabolic syndrome. Sleep. 2013;36(1):41-9. https://doi.org/ 10.5665/sleep.2298.

42. Somers VK, Mark AL, Zavala DC, Abboud FM. Contrasting effects of hypoxia and hypercapnia on ventilation and sympathetic activity in humans. J Appl Physiol (1985). 1989;67(5):2101-6. https:// doi.org/10.1152/jappl.1989.67.5.2101.

43. Somers VK, Mark AL, Abboud FM. Interaction of baroreceptor and chemoreceptor reflex control of sympathetic nerve activity in normal humans. J Clin Invest. 1991;87(6):1953-7. https://doi.org/10. 1172/JCI115221.

44. Fagard RH. Dipping pattern of nocturnal blood pressure in patients with hypertension. Expert Rev Cardiovasc Ther. 2009;7(6):599-605. https://doi. org/10.1586/erc.09.35.

45. Harris CD. Neurophysiology of sleep and wakefulness. Respir Care Clin N Am. 2005;11(4):567-86. https://doi.org/10.1016/j.rcc.2005.08.001.

46. Carlson JT, Hedner JA, Sellgren J, Elam M, Wallin BG. Depressed baroreflex sensitivity in patients with obstructive sleep apnea. Am J Respir Crit Care Med. 1996;154(5):1490-6. ajrccm.154.5.8912770.
47. Fletcher EC. Sympathetic over activity in the etiology of hypertension of obstructive sleep apnea. Sleep. 2003;26(1):15-9. https://doi.org/10.1093/ sleep/26.1.15.

48. Carlson JT, Hedner J, Elam M, Ejnell H, Sellgren J, Wallin BG. Augmented resting sympathetic activity in awake patients with obstructive sleep apnea. Chest. 1993;103(6):1763-8. https://doi.org/10. 1378/chest.103.6.1763.

49. Usui K, Bradley TD, Spaak J, et al. Inhibition of awake sympathetic nerve activity of heart failure patients with obstructive sleep apnea by nocturnal continuous positive airway pressure. J Am Coll Cardiol. 2005;45(12):2008-11. https://doi.org/10. 1016/j.jacc.2004.12.080.

50. Imadojemu VA, Mawji Z, Kunselman A, Gray KS, Hogeman CS, Leuenberger UA. Sympathetic chemoreflex responses in obstructive sleep apnea and effects of continuous positive airway pressure therapy. Chest. 2007;131:1406-13. https://doi.org/ 10.1378/chest.06-2580.

51. Bonsignore MR, Parati G, Insalaco G, et al. Continuous positive airway pressure treatment improves baroreflex control of heart rate during sleep in severe obstructive sleep apnea syndrome. Am J Respir Crit Care Med. 2002;166(3):279-86. https://doi.org/10.1164/rccm.2107117.

52. Noda A, Nakata S, Koike Y, et al. Continuous positive airway pressure improves daytime baroreflex sensitivity and nitric oxide production in patients with moderate to severe obstructive sleep apnea syndrome. Hypertens Res. 2007;30(8):669-76. https://doi.org/10.1291/hypres.30.669.

53. Huggett RJ, Scott EM, Gilbey SG, Stoker JB, Mackintosh AF, Mary DA. Impact of type 2 diabetes mellitus on sympathetic neural mechanisms in hypertension. Circulation. 2003;108(25):3097-101. https://doi.org/10.1161/01.CIR.0000103123.66264. FE.

54. Spallone V. Update on the impact, diagnosis and management of cardiovascular autonomic neuropathy in diabetes: what is defined, what is new, and what is unmet. Diabetes Metab J. 2019;43(1): 3-30. https://doi.org/10.4093/dmj.2018.0259.

55. Ziegler D, Strom A, Kupriyanova Y, GDS Group, et al. Association of lower cardiovagal tone and baroreflex sensitivity with higher liver fat content early in type 2 diabetes. J Clin Endocrinol Metab. 2018;103(3):1130-8. https://doi.org/10.1210/jc. 2017-02294.

56. Ziegler D, Strom A, Bönhof G, GDS Group, et al. Differential associations of lower cardiac vagal tone with insulin resistance and insulin secretion in 
recently diagnosed type 1 and type 2 diabetes. Metabolism. 2018;79:1-9. https://doi.org/10.1016/ j.metabol.2017.10.013.

57. Zoppini G, Cacciatori V, Raimondo D, et al. Prevalence of cardiovascular autonomic neuropathy in a cohort of patients with newly diagnosed type 2 diabetes: the Verona newly diagnosed type 2 diabetes study (VNDS). Diabetes Care. 2015;38(8): 1487-93. https://doi.org/10.2337/dc15-0081.

58. Hube F, Lietz U, Igel M, et al. Difference in leptin mRNA levels between omental and subcutaneous abdominal adipose tissue from obese humans. Horm Metab Res. 1996;28(12):690-3. https://doi. org/10.1055/s-2007-979879.

59. Shen J, Tanida M, Niijima A, Nagai K. In vivo effects of leptin on autonomic nerve activity and lipolysis in rats. Neurosci Lett. 2007;416(2):193-7. https:// doi.org/10.1016/j.neulet.2007.02.003.

60. Caron A, Lee S, Elmquist JK, Gautron L. Leptin and brain-adipose crosstalks. Nat Rev Neurosci. 2018;19(3):153-65. https://doi.org/10.1038/nrn. 2018.7.

61. Santos-Alvarez J, Goberna R, Sánchez-Margalet V. Human leptin stimulates proliferation and activation of human circulating monocytes. Cell Immunol. 1999;194(1):6-11. https://doi.org/10.1006/ cimm.1999.1490.

62. Han C, Wu W, Ale A, Kim MS, Cai D. Central Leptin and Tumor Necrosis Factor- $\alpha(\mathrm{TNF} \alpha)$ in Diurnal Control of Blood Pressure and Hypertension. J Biol Chem. 2016;291(29):15131-42. https://doi.org/10. 1074/jbc.M116.730408.

63. Mark AL. Selective leptin resistance revisited. Am J Physiol Regul Integr Comp Physiol. 2013;305(6): R566-81. https://doi.org/10.1152/ajpregu.00180. 2013.

64. Allison MA, Ix JH, Morgan C, et al. Higher leptin is associated with hypertension: the multi-ethnic study of atherosclerosis. J Hum Hypertens. 2013;27(10):617-22. https://doi.org/10.1038/jhh. 2013.24.

65. Pan W, Kastin AJ. Leptin: a biomarker for sleep disorders? Sleep Med Rev. 2014;18(3):283-90. https://doi.org/10.1016/j.smrv.2013.07.003.

66. Berger S, Polotsky VY. Leptin and leptin resistance in the pathogenesis of obstructive sleep apnea: a possible link to oxidative stress and cardiovascular complications. Oxid Med Cell Longev. 2018;2018: 5137947. https://doi.org/10.1155/2018/5137947.

67. Lüdemann P, Dziewas R, Sörös P, Happe S, Frese A. Axonal polyneuropathy in obstructive sleep apnoea. J Neurol Neurosurg Psychiatry. 2001;70(5): 685-7. https://doi.org/10.1136/jnnp.70.5.685.

68. Dziewas R, Schilling M, Engel P, et al. Treatment for obstructive sleep apnoea: effect on peripheral nerve function. J Neurol Neurosurg Psychiatry. 2007;78(3):295-7. https://doi.org/10.1136/jnnp. 2006.102806.

69. Schober AK, Neurath MF, Harsch IA. Prevalence of sleep apnoea in diabetic patients. Clin Respir J. 2011;5(3):165-72. https://doi.org/10.1111/j.1752699X.2010.00216.x.

70. Tahrani AA, Ali A, Raymond NT, et al. Obstructive sleep apnea and diabetic neuropathy: a novel association in patients with type 2 diabetes. Am J Respir Crit Care Med. 2012;186(5):434-41. https://doi.org/ 10.1164/rccm.201112-2135OC.

71. Fujihara K, Kodama S, Horikawa C, et al. The relationship between diabetic neuropathy and sleep apnea syndrome: a meta-analysis. Sleep Disord. 2013;2013:150371. https://doi.org/10.1155/2013/ 150371.

72. Altaf QA, Ali A, Piya MK, Raymond NT, Tahrani AA. The relationship between obstructive sleep apnea and intra-epidermal nerve fiber density, PARP activation and foot ulceration in patients with type 2 diabetes. J Diabetes Complicat. 2016;30(7):1315-20. https://doi.org/10.1016/j.jdiacomp.2016.05.025.

73. Leong WB, Jadhakhan F, Taheri S, Thomas GN, Adab P. The association between obstructive sleep apnea on diabetic kidney disease: a systematic review and meta-analysis. Sleep. 2016;39(2):301-8. https://doi.org/10.5665/sleep.5432.

74. Siwasaranond N, Nimitphong H, Manodpitipong A, et al. The relationship between diabetes-related complications and obstructive sleep apnea in type 2 diabetes. J Diabetes Res. 2018;2018:9269170. https://doi.org/10.1155/2018/9269170.

75. Tahrani AA, Ali A, Raymond NT, et al. Obstructive sleep apnea and diabetic nephropathy: a cohort study. Diabetes Care. 2013;36(11):3718-25. https:// doi.org/10.2337/dc13-0450.

76. Tahrani AA, Dubb K, Raymond NT, et al. Cardiac autonomic neuropathy predicts renal function decline in patients with type 2 diabetes: a cohort study. Diabetologia. 2014;57(6):1249-56. https:// doi.org/10.1007/s00125-014-3211-2.

77. Yun JS, Ahn YB, Song KH, et al. The association between abnormal heart rate variability and new onset of chronic kidney disease in patients with type 2 diabetes: a ten-year follow-up study. Diabetes Res Clin Pract. 2015;108(1):31-7. https://doi.org/ 10.1016/j.diabres.2015.01.031. 
78. Faulx MD, Storfer-Isser A, Kirchner HL, et al. Obstructive sleep apnea is associated with increased urinary albumin excretion. Sleep. 2007;30(7):923-9. https://doi.org/10.1093/sleep/30.7.923.

79. Iseki K, Tohyama K, Matsumoto T, Nakamura H. High prevalence of chronic kidney disease among patients with sleep related breathing disorder (SRBD). Hypertens Res. 2008;31(2):249-55. https:// doi.org/10.1291/hypres.31.249.

80. Kanbay A, Buyukoglan H, Ozdogan N, et al. Obstructive sleep apnea syndrome is related to the progression of chronic kidney disease. Int Urol Nephrol. 2012;44(2):535-9. https://doi.org/10. 1007/s11255-011-9927-8.

81. Leong WB, Nolen M, Thomas GN, Adab P, Banerjee $\mathrm{D}$, Taheri S. The impact of hypoxemia on nephropathy in extremely obese patients with type 2 diabetes mellitus. J Clin Sleep Med. 2014;10(7): 773-8. https://doi.org/10.5664/jcsm.3870.

82. Bulcun E, Ekici M, Ekici A, Cimen DA, Kisa U. Microalbuminuria in obstructive sleep apnea syndrome. Sleep Breath. 2015;19(4):1191-7. https:// doi.org/10.1007/s11325-015-1136-8.

83. Hanly P. Sleep disorders and end-stage renal disease. Curr Opin Pulm Med. 2008;14(6):543-50. https:// doi.org/10.1097/MCP.0b013e3283130f96.

84. Tada T, Kusano KF, Ogawa A, et al. The predictors of central and obstructive sleep apnoea in haemodialysis patients. Nephrol Dial Transplant. 2007;22(4):1190-7. https://doi.org/10.1093/ndt/ gfl748.

85. Hanly P. Sleep apnea and daytime sleepiness in endstage renal disease. Semin Dial. 2004;17(2):109-14. https://doi.org/10.1111/j.0894-0959.2004.17206.x.

86. Abuyassin B, Sharma K, Ayas NT, Laher I. Obstructive sleep apnea and kidney disease: a potential bidirectional relationship? J Clin Sleep Med. 2015;11(8):915-24. https://doi.org/10.5664/jcsm. 4946.

87. Leong WB, Jadhakhan F, Taheri S, Chen YF, Adab P, Thomas GN. Effect of obstructive sleep apnoea on diabetic retinopathy and maculopathy: a systematic review and meta-analysis. Diabet Med. 2016;33(2): 158-68. https://doi.org/10.1111/dme.12817.

88. Zhu Z, Zhang F, Liu Y, et al. Relationship of obstructive sleep apnoea with diabetic retinopathy: a meta-analysis. Biomed Res Int. 2017;2017: 4737064. https://doi.org/10.1155/2017/4737064.

89. Shiba T, Sato Y, Takahashi M. Relationship between diabetic retinopathy and sleep-disordered breathing. Am J Ophthalmol. 2009;147(6):1017-21. https://doi.org/10.1016/j.ajo.2008.12.027.

90. Shiba T, Maeno T, Saishin Y, Hori Y, Takahashi M. Nocturnal intermittent serious hypoxia and reoxygenation in proliferative diabetic retinopathy cases. Am J Ophthalmol. 2010;149(6):959-63. https://doi. org/10.1016/j.ajo.2010.01.006.

91. Verdecchia P, Angeli F, Mazzotta G, et al. Day-night dip and early-morning surge in blood pressure in hypertension: prognostic implications. Hypertension. 2012;60(1):34-42. https://doi.org/10.1161/ HYPERTENSIONAHA.112.191858.

92. Najafi MT, Khaloo P, Alemi H, et al. Ambulatory blood pressure monitoring and diabetes complications: targeting morning blood pressure surge and nocturnal dipping. Medicine (Baltimore). 2018;97(38):e12185. https://doi.org/10.1097/MD. 0000000000012185 .

93. Altaf QA, Dodson P, Ali A, et al. Obstructive sleep apnea and retinopathy in patients with type 2 diabetes. A longitudinal study. Am J Respir Crit Care Med. 2017;196(7):892-900. https://doi.org/10. 1164/rccm.201701-0175OC.

94. Bradley TD, Floras JS. Obstructive sleep apnoea and its cardiovascular consequences. Lancet. 2009;373(9657):82-93. https://doi.org/10.1016/ S0140-6736(08)61622-0.

95. Seicean S, Strohl KP, Seicean A, Gibby C, Marwick TH. Sleep disordered breathing as a risk of cardiac events in subjects with diabetes mellitus and normal exercise echocardiographic findings. Am J Cardiol. 2013;111(8):1214-20. https://doi.org/10. 1016/j.amjcard.2012.12.053.

96. Foster GD, Borradaile KE, Sanders MH, Sleep AHEAD Research Group of Look AHEAD Research Group, et al. A randomized study on the effect of weight loss on obstructive sleep apnea among obese patients with type 2 diabetes: the Sleep AHEAD study. Arch Intern Med. 2009;169(17):1619-26. https://doi.org/10.1001/archinternmed.2009.266.

97. Look Ahead Research Group, Bray G, Gregg E, Haffner S, et al. Baseline characteristics of the randomised cohort from the Look AHEAD (Action for Health in Diabetes) study. Diabetes Vasc Dis Res. 2006;3(3):202-15. https://doi.org/10.3132/dvdr. 2006.031 .

98. Rice TB, Foster GD, Sanders MH, Sleep AHEAD Research Group, et al. The relationship between obstructive sleep apnea and self-reported stroke or coronary heart disease in overweight and obese adults with type 2 diabetes mellitus. Sleep. 2012;35(9):1293-8. https://doi.org/10.5665/sleep. 2090. 
99. Arzt M, Young T, Finn L, Skatrud JB, Bradley TD. Association of sleep-disordered breathing and the occurrence of stroke. Am J Respir Crit Care Med. 2005;172(11):1447-51. https://doi.org/10.1164/ rccm.200505-702OC.

100. Redline S, Yenokyan G, Gottlieb DJ, et al. Obstructive sleep apnea-hypopnea and incident stroke: the sleep heart health study. Am J Respir Crit Care Med. 2010;182(2):269-77. https://doi.org/10.1164/rccm. 200911-1746OC.

101. Gottlieb DJ, Yenokyan G, Newman AB, et al. Prospective study of obstructive sleep apnea and incident coronary heart disease and heart failure: the sleep heart health study. Circulation. 2010;122(4):352-60. https://doi.org/10.1161/ CIRCULATIONAHA.109.901801.

102. Shen H, Zhao J, Liu Y, Sun G. Interactions between and shared molecular mechanisms of diabetic peripheral neuropathy and obstructive sleep apnea in type 2 diabetes patients. J Diabetes Res. 2018;2018:3458615. https://doi.org/10.1155/2018/ 3458615 .

103. Nannapaneni S, Ramar K, Surani S. Effect of obstructive sleep apnea on type 2 diabetes mellitus: a comprehensive literature review. World J Diabetes. 2013;4(6):238-44. https://doi.org/10.4239/ wjd.v4.i6.238.

104. Adeshara KA, Diwan AG, Tupe RS. Diabetes and complications: cellular signaling pathways, current understanding and targeted therapies. Curr Drug Targets. 2016;17(11):1309-28. https://doi.org/10. 2174/1389450117666151209124007.

105. Beisswenger PJ, Makita Z, Curphey TJ, et al. Formation of immunochemical advanced glycosylation end products precedes and correlates with early manifestations of renal and retinal disease in diabetes. Diabetes. 1995;44(7):824-9. https://doi.org/ 10.2337/diab.44.7.824.

106. Ramasamy R, Yan SF, Schmidt AM. The diverse ligand repertoire of the receptor for advanced glycation end products and pathways to the complications of diabetes. Vascul Pharmacol. 2012;57(5-6):160-7. https://doi.org/10.1016/j.vph. 2012.06.004.

107. Wada J, Makino H. Inflammation and the pathogenesis of diabetic nephropathy. Clin Sci (Lond). 2013;124(3):139-52. https://doi.org/10.1042/ CS20120198.

108. Xu J, Chen LJ, Yu J, et al. Involvement of advanced glycation end products in the pathogenesis of diabetic retinopathy. Cell Physiol Biochem. 2018;48(2):705-17. https://doi.org/10.1159/ 000491897.
109. Lavie L. Oxidative stress inflammation and endothelial dysfunction in obstructive sleep apnea. Front Biosci (Elite Ed). 2012;4:1391-403. https:// doi.org/10.2741/469 (PMID: 22201964).

110. Umeno A, Biju V, Yoshida Y. In vivo ROS production and use of oxidative stress-derived biomarkers to detect the onset of diseases such as Alzheimer's disease, Parkinson's disease, and diabetes. Free Radic Res. 2017;51(4):413-27. https://doi.org/10. 1080/10715762.2017.1315114.

111. Wang N, Khan SA, Prabhakar NR, Nanduri J. Impairment of pancreatic $\beta$-cell function by chronic intermittent hypoxia. Exp Physiol. 2013;98(9): 1376-85. https://doi.org/10.1113/expphysiol.2013. 072454 .

112. Fiedorczuk P, Stróżyński A, Olszewska E. Is the oxidative stress in obstructive sleep apnea associated with cardiovascular complications? Systematic review. J Clin Med. 2020;9(11):3734. https://doi. org/10.3390/jcm9113734.

113. Lavie L. Oxidative stress: a unifying paradigm in obstructive sleep apnea and comorbidities. Prog Cardiovasc Dis. 2009;51(4):303-12. https://doi.org/ 10.1016/j.pcad.2008.08.003.

114. Turek NF, Ricardo AC, Lash JP. Sleep disturbances as non traditional risk factors for development and progression of CKD: review of the evidence. Am J Kidney Dis. 2012;60(5):823-33. https://doi.org/10. 1053/j.ajkd.2012.04.027.

115. Sakaguchi Y, Hatta T, Hayashi T, et al. Association of nocturnal hypoxemia with progression of CKD. Clin J Am Soc Nephrol. 2013;8(9):1502-7. https:// doi.org/10.2215/CJN.11931112.

116. Nowakowski S, Matthews KA, von Känel R, Hall $\mathrm{MH}$, Thurston RC. Sleep characteristics and inflammatory biomarkers among midlife women. Sleep. 2018;41(5):zsy049. https://doi.org/10.1093/ sleep/zsy049.

117. Nadeem R, Molnar J, Madbouly EM, et al. Serum inflammatory markers in obstructive sleep apnea: a meta-analysis. J Clin Sleep Med. 2013;9(10): 1003-12. https://doi.org/10.5664/jcsm.3070.

118. Kheirandish-Gozal L, Gozal D. Obstructive sleep apnea and inflammation: proof of concept based on two illustrative cytokines. Int J Mol Sci. 2019;20(3): 459. https://doi.org/10.3390/ijms20030459.

119. Barone MT, Menna-Barreto L. Diabetes and sleep: a complex cause-and-effect relationship. Diabetes Res Clin Pract. 2011;91(2):129-37. https://doi.org/10. 1016/j.diabres.2010.07.011. 
120. Assar ME, Angulo J, Rodríguez-Mañas L. Diabetes and ageing-induced vascular inflammation. J Physiol. 2016;594(8):2125-46. https://doi.org/10.1113/ JP270841.

121. Cimini FA, Barchetta I, Porzia A, et al. Circulating IL-8 levels are increased in patients with type 2 diabetes and associated with worse inflammatory and cardiometabolic profile. Acta Diabetol. 2017;54(10):961-7. https://doi.org/10.1007/ s00592-017-1039-1.

122. Ning Y, Zhang TS, Wen WW, et al. Effects of continuous positive airway pressure on cardiovascular biomarkers in patients with obstructive sleep apnea: a meta-analysis of randomized controlled trials. Sleep Breath. 2019;23(1):77-86. https://doi.org/10. 1007/s11325-018-1662-2.

123. Xu JX, Cai W, Sun JF, et al. Serum advanced glycation end products are associated with insulin resistance in male nondiabetic patients with obstructive sleep apnea. Sleep Breath. 2015;19(3):827-33. https://doi.org/10.1007/s11325-014-1100-z.

124. Tan KC, Chow WS, Lam JC, et al. Advanced glycation endproducts in nondiabetic patients with obstructive sleep apnea. Sleep. 2006;29(3):329-33. https://doi.org/10.1093/sleep/29.3.329.

125. Wu X, She W, Niu X, Chen X. Association between serum level of advanced glycation end products and obstructive sleep apnea-hypopnea syndrome: a meta-analysis. J Int Med Res. 2018;46(11):4377-85. https://doi.org/10.1177/0300060518786906.

126. Marrone O, Battaglia S, Steiropoulos P, ESADA Study Group, et al. Chronic kidney disease in European patients with obstructive sleep apnea: the ESADA cohort study. J Sleep Res. 2016;25(6): 739-45. https://doi.org/10.1111/jsr.12426.

127. Adams RJ, Appleton SL, Vakulin A, et al. Chronic kidney disease and sleep apnea association of kidney disease with obstructive sleep apnea in a population study of men. Sleep. 2017. https://doi.org/ 10.1093/sleep/zsw015.

128. Lee YC, Hung SY, Wang HK, et al. Sleep apnea and the risk of chronic kidney disease: a nationwide population-based cohort study. Sleep. 2015;38: 213-21. https://doi.org/10.5665/sleep.4400.

129. Chu H, Shih CJ, Ou SM, Chou KT, Lo YH, Chen YT. Association of sleep apnoea with chronic kidney disease in a large cohort from Taiwan. Respirology. 2016;21(4):754-60. https://doi.org/10.1111/resp. 12739.

130. Lin YS, Liu PH, Lin SW, et al. Simple obstructive sleep apnea patients without hypertension or diabetes accelerate kidney dysfunction: a population follow-up cohort study from Taiwan. Sleep Breath. 2017;21:85-91. https://doi.org/10.1007/s11325016-1376-2.

131. Dou L, Lan H, Reynolds DJ, et al. Association between obstructive sleep apnea and acute kidney injury in critically ill patients: a propensity-matched study. Nephron. 2017;135(2):137-46. https:// doi.org/10.1159/000453367.

132. Lin CH, Perger E, Lyons OD. Obstructive sleep apnea and chronic kidney disease. Curr Opin Pulm Med. 2018;24(6):549-54. https://doi.org/10.1097/ MCP.0000000000000525.

133. Muraki I, Wada H, Tanigawa T. Sleep apnea and type 2 diabetes. J Diabetes Investig. 2018;9(5): 991-7. https://doi.org/10.1111/jdi.12823.

134. Zinman B, Wanner C, Lachin JM, EMPA-REG OUTCOME Investigators, et al. Empagliflozin, cardiovascular outcomes, and mortality in type 2 diabetes. N Engl J Med. 2015;373(22):2117-28. https:// doi.org/10.1056/NEJMoa1504720.

135. Neal B, Perkovic V, Mahaffey KW, CANVAS Program Collaborative Group, et al. Canagliflozin and cardiovascular and renal events in type 2 diabetes. N Engl J Med. 2017;377(7):644-57. https://doi.org/ 10.1056/NEJMoa1611925.

136. McMurray JJV, Solomon SD, Inzucchi SE, DAPA-HF Trial Committees and Investigators, et al. Dapagliflozin in patients with heart failure and reduced ejection fraction. N Engl J Med. 2019;381(21): 1995-2008. NEJMoa1911303.

137. Cosentino F, Cannon CP, Cherney DZI, VERTIS CV Investigators, et al. Efficacy of ertugliflozin on heart failure-related events in patients with type 2 diabetes mellitus and established atherosclerotic cardiovascular disease: results of the VERTIS CV trial. Circulation. 2020;142(23):2205-15. https://doi.org/ 10.1161/CIRCULATIONAHA.120.050255.

138. Wiviott SD, Raz I, Bonaca MP, DECLARE-TIMI 58 Investigators, et al. Dapagliflozin and cardiovascular outcomes in type 2 diabetes. $\mathrm{N}$ Engl J Med. 2019;380(4):347-57. https://doi.org/10.1056/ NEJMoa1812389.

139. Packer M, Anker SD, Butler J, EMPEROR-Reduced Trial Committees and Investigators, et al. Effect of empagliflozin on the clinical stability of patients with heart failure and a reduced ejection fraction: the EMPEROR-Reduced Trial. Circulation. 2020. https://doi.org/10.1161/CIRCULATIONAHA.120. 051783.

140. Perkovic V, Jardine MJ, Neal B, CREDENCE Trial Investigators, et al. Canagliflozin and renal 
outcomes in type 2 diabetes and nephropathy. N Engl J Med. 2019;380(24):2295-306. https://doi. org/10.1056/NEJMoa1811744.

141. Heerspink HJL, Stefánsson BV, Correa-Rotter R, DAPA-CKD Trial Committees and Investigators, et al. Dapagliflozin in patients with chronic kidney disease. N Engl J Med. 2020;383(15):1436-46. https://doi.org/10.1056/NEJMoa2024816.

142. Tentolouris A, Vlachakis P, Tzeravini E, Eleftheriadou I, Tentolouris N. SGLT2 inhibitors: a review of their antidiabetic and cardioprotective effects. Int J Environ Res Public Health. 2019;16(16):2965. https://doi.org/10.3390/ijerph16162965.

143. Wright EM. Renal $\mathrm{Na}(+)$-glucose cotransporters. Am J Physiol Renal Physiol. 2001;280(1):F10-8. https://doi.org/10.1152/ajprenal.2001.280.1.F10.

144. Wright EM, Loo DD, Hirayama BA. Biology of human sodium glucose transporters. Physiol Rev. 2011;91(2):733-94. https://doi.org/10.1152/ physrev.00055.2009.

145. Vrhovac I, Balen Eror D, Klessen D, et al. Localizations of $\mathrm{Na}(+)$-D-glucose cotransporters SGLT1 and SGLT2 in human kidney and of SGLT1 in human small intestine, liver, lung, and heart. Pflugers Arch. 2015;467(9):1881-98. https://doi.org/10.1007/ s00424-014-1619-7.

146. Song P, Onishi A, Koepsell H, Vallon V. Sodium glucose cotransporter SGLT1 as a therapeutic target in diabetes mellitus. Expert Opin Ther Targets. 2016;20(9):1109-25. https://doi.org/10.1517/ 14728222.2016.1168808.

147. Sano R, Shinozaki Y, Ohta T. Sodium-glucose cotransporters: Functional properties and pharmaceutical potential. J Diabetes Investig. 2020;11(4): 770-82. https://doi.org/10.1111/jdi.13255.

148. Kaur J, Young BE, Fadel PJ. Sympathetic overactivity in chronic kidney disease: consequences and mechanisms. Int J Mol Sci. 2017;18:E1682. https:// doi.org/10.3390/ijms18081682.

149. Sano M. A new class of drugs for heart failure: SGLT2 inhibitors reduce sympathetic overactivity. J Cardiol. 2018;71(5):471-6. https://doi.org/10. 1016/j.jjcc.2017.12.004.

150. Kosiborod M, Cavender MA, Fu AZ, CVD-REAL Investigators and Study Group, et al. Lower risk of heart failure and death in patients initiated on sodium-glucose cotransporter- 2 inhibitors versus other glucose-lowering drugs: the CVD-REAL study (comparative effectiveness of cardiovascular outcomes in new users of sodium-glucose cotransporter-2 inhibitors). Circulation. 2017;136(3):
249-59. CIRCULATIONAHA.117.029190.

https://doi.org/10.1161/

151. Kim YG, Han SJ, Kim DJ, Lee KW, Kim HJ. Association between sodium glucose co-transporter 2 inhibitors and a reduced risk of heart failure in patients with type 2 diabetes mellitus: a real-world nationwide population-based cohort study. Cardiovasc Diabetol. 2018;17(1):91. https://doi.org/10. 1186/s12933-018-0737-5.

152. Thomson SC, Rieg T, Miracle C, et al. Acute and chronic effects of SGLT2 blockade on glomerular and tubular function in the early diabetic rat. Am J Physiol Regul Integr Comp Physiol. 2012;302(1): R75-83. https://doi.org/10.1152/ajpregu.00357. 2011.

153. Vallon V, Gerasimova M, Rose MA, et al. SGLT2 inhibitor empagliflozin reduces renal growth and albuminuria in proportion to hyperglycemia and prevents glomerular hyperfiltration in diabetic Akita mice. Am J Physiol Renal Physiol. 2014;306(2):F194-204. https://doi.org/10.1152/ ajprenal.00520.2013.

154. Vallon V, Rose M, Gerasimova M, et al. Knockout of Na-glucose transporter SGLT2 attenuates hyperglycemia and glomerular hyperfiltration but not kidney growth or injury in diabetes mellitus. Am J Physiol Renal Physiol. 2013;304(2):F156-67. https://doi.org/10.1152/ajprenal.00409.2012.

155. Schnermann J, Persson AE, Agerup B. Tubuloglomerular feedback. Nonlinear relation between glomerular hydrostatic pressure and loop of henle perfusion rate. J Clin Invest. 1973;52(4):862-9. https://doi.org/10.1172/JCI107250.

156. Castrop H. Mediators of tubuloglomerular feedback regulation of glomerular filtration: ATP and adenosine. Acta Physiol (Oxf). 2007;189(1):3-14. https://doi.org/10.1111/j.1748-1716.2006.01610.x.

157. Hansen PB, Hashimoto S, Oppermann M, Huang Y, Briggs JP, Schnermann J. Vasoconstrictor and vasodilator effects of adenosine in the mouse kidney due to preferential activation of A1 or A2 adenosine receptors. J Pharmacol Exp Ther. 2005;315(3):1150-7. https://doi.org/10.1124/jpet. 105.091017 .

158. Rabadi MM, Lee HT. Adenosine receptors and renal ischaemia reperfusion injury. Acta Physiol (Oxf). 2015;213(1):222-31. https://doi.org/10.1111/apha. 12402.

159. Carlström M, Wilcox CS, Welch WJ. Adenosine A2A receptor activation attenuates tubuloglomerular feedback responses by stimulation of endothelial nitric oxide synthase. Am J Physiol Renal Physiol. 
2011;300(2):F457-64. ajprenal.00567.2010.

https://doi.org/10.1152/

160. Lai EY, Patzak A, Steege A, et al. Contribution of adenosine receptors in the control of arteriolar tone and adenosine-angiotensin II interaction. Kidney Int. 2006;70(4):690-8. https://doi.org/10.1038/sj.ki. 5001650 .

161. Cherney DZ, Perkins BA, Soleymanlou N, et al. Sodium glucose cotransport-2 inhibition and intrarenal RAS activity in people with type 1 diabetes. Kidney Int. 2014;86(5):1057-8. https://doi. org/10.1038/ki.2014.246.

162. Yoshimoto T, Furuki T, Kobori H, Miyakawa M, Imachi H, Murao K, Nishiyama A. Effects of sodiumglucose cotransporter 2 inhibitors on urinary excretion of intact and total angiotensinogen in patients with type 2 diabetes. J Investig Med. 2017;65(7):1057-61. https://doi.org/10.1136/jim2017-000445.

163. Shin SJ, Chung S, Kim SJ, et al. Effect of sodiumglucose co-transporter 2 inhibitor, dapagliflozin, on renal renin-angiotensin system in an animal model of type 2 diabetes. PLoS ONE. 2016;11(11): e0165703. https://doi.org/10.1371/journal.pone. 0165703.

164. Lopaschuk GD, Verma S. Mechanisms of cardiovascular benefits of sodium glucose co-transporter 2 (SGLT2) inhibitors: a state-of-the-art review. JACC Basic Transl Sci. 2020;5(6):632-44. https://doi.org/ 10.1016/j.jacbts.2020.02.004.

165. Körner A, Eklöf AC, Celsi G, Aperia A. Increased renal metabolism in diabetes. Mechanism and functional implications. Diabetes. 1994;43(5): 629-33. https://doi.org/10.2337/diab.43.5.629.

166. Gewin L, Zent R, Pozzi A. Progression of chronic kidney disease: too much cellular talk causes damage. Kidney Int. 2017;91(3):552-60. https://doi.org/ 10.1016/j.kint.2016.08.025.

167. Asada N, Takase M, Nakamura J, et al. Dysfunction of fibroblasts of extrarenal origin underlies renal fibrosis and renal anemia in mice. J Clin Invest. 2011;121(10):3981-90. https://doi.org/10.1172/ JCI57301.

168. Bosman DR, Winkler AS, Marsden JT, Macdougall IC, Watkins PJ. Anemia with erythropoietin deficiency occurs early in diabetic nephropathy. Diabetes Care. 2001;24(3):495-9. https://doi.org/10. 2337/diacare.24.3.495.

169. Sano M, Goto S. Possible mechanism of hematocrit elevation by sodium glucose cotransporter 2 inhibitors and associated beneficial renal and cardiovascular effects. Circulation. 2019;139(17):1985-7.
https://doi.org/10.1161/CIRCULATIONAHA.118. 038881.

170. Lambers Heerspink HJ, de Zeeuw D, Wie L, Leslie B, List J. Dapagliflozin a glucose-regulating drug with diuretic properties in subjects with type 2 diabetes. Diabetes Obes Metab. 2013;15(9):853-62. https:// doi.org/10.1111/dom.12127.

171. Ferrannini E, Baldi S, Frascerra S, et al. Renal handling of ketones in response to sodium-glucose cotransporter 2 inhibition in patients with type 2 diabetes. Diabetes Care. 2017;40(6):771-6. https:// doi.org/10.2337/dc16-2724.

172. Bolinder J, Ljunggren Ö, Kullberg J, et al. Effects of dapagliflozin on body weight, total fat mass, and regional adipose tissue distribution in patients with type 2 diabetes mellitus with inadequate glycemic control on metformin. J Clin Endocrinol Metab. 2012;97(3):1020-31. https://doi.org/10.1210/jc. 2011-2260.

173. Bolinder J, Ljunggren Ö, Johansson L, et al. Dapagliflozin maintains glycaemic control while reducing weight and body fat mass over 2 years in patients with type 2 diabetes mellitus inadequately controlled on metformin. Diabetes Obes Metab. 2014;16(2):159-69. https://doi.org/10.1111/dom. 12189.

174. Cefalu WT, Leiter LA, Yoon KH, et al. Efficacy and safety of canagliflozin versus glimepiride in patients with type 2diabetes inadequately controlled with metformin (CANTATA-SU): 52 week results from a randomised, double-blind, phase 3 non-inferiority trial. Lancet. 2013;382(9896):941-50. https://doi. org/10.1016/S0140-6736(13)60683-2.

175. Yokono M, Takasu T, Hayashizaki Y, et al. SGLT2 selective inhibitor ipragliflozin reduces body fat mass by increasing fatty acid oxidation in high-fat diet-induced obese rats. Eur J Pharmacol. 2014;15(727):66-74. https://doi.org/10.1016/j. ejphar.2014.01.040.

176. Liang Y, Arakawa K, Ueta K, et al. Effect of canagliflozin on renal threshold for glucose, glycemia, and body weight in normal and diabetic animal models. PLoS ONE. 2012;7(2):e30555. https://doi. org/10.1371/journal.pone.0030555.

177. Yokono M, Takasu T, Hayashizaki Y, et al. SGLT2 selective inhibitor ipragliflozin reduces body fat mass by increasing fatty acid oxidation in high-fat diet-induced obese rats. Eur J Pharmacol. 2014;727: 66-74. https://doi.org/10.1016/j.ejphar.2014.01. 040.

178. Suzuki M, Takeda M, Kito A, et al. Tofogliflozin, a sodium/glucose cotransporter 2 inhibitor, attenuates body weight gain and fat accumulation in 
diabetic and obese animal models. Nutr Diabetes. 2014;4:e125. https://doi.org/10.1038/nutd.2014.20.

179. Ferrannini E, Muscelli E, Frascerra S, et al. Metabolic response to sodium-glucose cotransporter 2 inhibition in type 2 diabetic patients. J Clin Invest. 2014;124(2):499-508. https://doi.org/10.1172/ JCI72227.

180. Itani T, Ishihara T. Efficacy of canagliflozin against nonalcoholic fatty liver disease: a prospective cohort study. Obes Sci Pract. 2018;4(5):477-82. https://doi.org/10.1002/osp4.294.

181. Raj H, Durgia H, Palui R, et al. SGLT-2 inhibitors in non-alcoholic fatty liver disease patients with type 2 diabetes mellitus: a systematic review. World J Diabetes. 2019;10(2):114-32. https://doi.org/10. 4239/wjd.v10.i2.114.

182. Choi DH, Jung CH, Mok JO, Kim CH, Kang SK, Kim BY. Effect of dapagliflozin on alanine aminotransferase improvement in type 2 diabetes mellitus with non-alcoholic fatty liver disease. Endocrinol Metab (Seoul). 2018;33(3):387-94. https://doi.org/10. 3803/EnM.2018.33.3.387.

183. Shimizu M, Suzuki K, Kato K, et al. Evaluation of the effects of dapagliflozin, a sodium-glucose co-transporter-2 inhibitor, on hepatic steatosis and fibrosis using transient elastography in patients with type 2 diabetes and non-alcoholic fatty liver disease. Diabetes Obes Metab. 2019;21(2):285-92. https://doi. org/10.1111/dom. 13520.

184. Omori K, Nakamura A, Miyoshi H, et al. Effects of dapagliflozin and/or insulin glargine on beta cell mass and hepatic steatosis in $\mathrm{db} / \mathrm{db}$ mice. Metabolism. 2019;98:27-36. https://doi.org/10.1016/j. metabol.2019.06.006.

185. Yagi S, Hirata Y, Ise T, et al. Canagliflozin reduces epicardial fat in patients with type 2 diabetes mellitus. Diabetol Metab Syndr. 2017;4(9):78. https:// doi.org/10.1186/s13098-017-0275-4.

186. Shimabukuro M, Hirata Y, Tabata M, et al. Epicardial adipose tissue volume and adipocytokine imbalance are strongly linked to human coronary atherosclerosis. Arterioscler Thromb Vasc Biol. 2013;33(5):1077-84. https://doi.org/10.1161/ ATVBAHA.112.300829.

187. Mahabadi AA, Lehmann N, Kälsch H, et al. Association of epicardial adipose tissue with progression of coronary artery calcification is more pronounced in the early phase of atherosclerosis: results from the Heinz Nixdorf recall study. JACC Cardiovasc Imaging. 2014;7(9):909-16. https://doi.org/10. 1016/j.jcmg.2014.07.002.
188. Spallone V, Valensi P. SGLT2 inhibitors and the autonomic nervous system in diabetes: a promising challenge to better understand multiple target improvement. Diabetes Metab. 2021;47:101224. https://doi.org/10.1016/j.diabet.2021.101224.

189. Li N, Li HP, Wang P, Yan YR, Li SQ, Li QY. Nocturnal mean oxygen saturation is associated with secondary polycythemia in young adults with obstructive sleep apnea, especially in men. Nat Sci Sleep. 2019;11:377-86. https://doi.org/10.2147/ NSS.S226143.

190. Grau M, Cremer JM, Schmeichel S, Kunkel M, Bloch W. Comparisons of blood parameters, red blood cell deformability and circulating nitric oxide between males and females considering hormonal contraception: a longitudinal gender study. Front Physiol. 2018;9:1835. https://doi.org/10.3389/fphys.2018. 01835 .

191. Inzucchi SE, Zinman B, Fitchett D, et al. How does empagliflozin reduce cardiovascular mortality? Insights from a mediation analysis of the EMPAREG OUTCOME Trial. Diabetes Care. 2018;41(2): 356-63. https://doi.org/10.2337/dc17-1096.

192. Sawada K, Karashima S, Kometani M, et al. Effect of sodium glucose cotransporter 2 inhibitors on obstructive sleep apnea in patients with type 2 diabetes. Endocr J. 2018;65(4):461-7. https://doi. org/10.1507/endocrj.EJ17-0440.

193. Tang Y, Sun Q, Bai XY, Zhou YF, Zhou QL, Zhang M. Effect of dapagliflozin on obstructive sleep apnea in patients with type 2 diabetes: a preliminary study. Nutr Diabetes. 2019;9(1):32. https://doi.org/ 10.1038/s41387-019-0098-5.

194. Johns MW. A new method for measuring daytime sleepiness: the Epworth sleepiness scale. Sleep. 1991;14(6):540-5. https://doi.org/10.1093/sleep/14. 6.540 .

195. Yoshimoto T, Furuki T, Kobori H, et al. Effects of sodium-glucose cotransporter 2 inhibitors on urinary excretion of intact and total angiotensinogen in patients with type 2 diabetes. J Investig Med. 2017;65(7):1057-61. https://doi.org/10.1136/jim2017-000445.

196. Neeland IJ, Eliasson B, Kasai T, EMPA-REG OUTCOME Investigators, et al. The impact of empagliflozin on obstructive sleep apnea and cardiovascular and renal outcomes: an exploratory analysis of the EMPA-REG OUTCOME Trial. Diabetes Care. 2020;43(12):3007-15. https://doi.org/10.2337/ dc20-1096.

197. Packer M. Do sodium-glucose co-transporter-2 inhibitors prevent heart failure with a preserved ejection fraction by counterbalancing the effects of 
leptin? A novel hypothesis. Diabetes Obes Metab. 2018;20(6):1361-6. https://doi.org/10.1111/dom. 13229.

198. Avogaro A, Fadini GP. Counterpoint to the hypothesis that SGLT2 inhibitors protect the heart by antagonizing leptin. Diabetes Obes Metab. 2018;20(6):1367-8. https://doi.org/10.1111/dom. 13234.

199. Wu P, Wen W, Li J, et al. Systematic review and meta-analysis of randomized controlled trials on the effect of SGLT2 inhibitor on blood leptin and adiponectin level in patients with type 2 diabetes. Horm Metab Res. 2019;51(8):487-94. https://doi. org/10.1055/a-0958-2441.

200. Jhund PS, Solomon SD, Docherty KF, et al. Efficacy of dapagliflozin on renal function and outcomes in patients with heart failure with reduced ejection fraction: results of DAPA-HF. Circulation. 2021;143(4):298-309. 